\title{
Effects of plyometric training on explosive strength of lower limb for young athletes
}

\author{
Daoye $\mathrm{Lu}^{1, \text { a }}$ \\ ${ }^{1}$ Shandong Sport University, Jinan, shandong, China \\ aludaoye@yeah.net
}

Keywords: plyometric training; lower limbs; explosive strength; young athletes.

\begin{abstract}
In this paper, 10 volleyball young athletes and 10 badminton young athletes were selected as the object of study, randomly dividing into control group and experimental group. The normal strength training was used in control group and plyometric training was used in experimental group. After eight weeks, the results show that firstly, plyometric training significantly improved the explosive effect of lower limbs for young athletes, especially on the indicators of vertical jump to touch and single vertical jump; secondly, plyometric training cannot significantly improve biggest strength of lower limbs for young athletes. It also indicates that the improvement of explosive power of lower limbs does not depend on the improvement of biggest strength of lower limbs for young athletes. The normal strength training is better than plyometric training for biggest strength training for young athletes. Therefore, we suggest that the plyometric training for young athletes should be gradual and limited load. There is a difference between young and adult athletes for the intensity and measurement of plyometric training that will not take adverse reactions in the body for young athletes.
\end{abstract}

\section{Introduction}

The explosive force training plays an important role in lower limbs explosive force training in the physical training of adolescent athletes. Explosive force can make the athletes with higher efficiency, more effective energy transfer. When the athlete requires rapid change of speed and strength, they must have explosive force on upper and lower limbs. For example, volleyball requires the explosive vertical bounce around with fast displacement, football emphasizes the explosive speed play, stop, explosive force and displacement jumps for the ball, table tennis requires the strength at the foot of ground and explosive force action, badminton need to jump to kill the ball, etc. They all need the arms with super power. the lower limbs explosive force training for young athletes is an important part of physical training, with an important theoretical and practical significance. We can explore to rapidly improve explosive force of lower limbs for young athletes through scientific experimental methods and closely combing with the training practice. Based on this training method, improvement of youth athlete's scientific training methods can supply better service in the sports fitness training work.

\section{Study content and method}

Study object. The basic information of participants: Number20, Age(year)17.5 \pm 2.2 , Height $(\mathrm{cm}) 178.3 \pm 6.56$, Weight $(\mathrm{kg}) 67.6 \pm 5.87$.

The training information of participants: Number: 10,Training program: Volleyball,Level: First class, Training time(Year): 5.

The training information of participants:

Number: 10,Training program: Badminton,Level: First class (Number: 4); Second class(Number: 6) Training time(Year): 5 Year(Number: 3); 4Year(Number: 7)

Test equipment. The experimental test data were collected by KISTLER Quattro Jump, GYM/AWARE and CMJ. Other experimental equipment included: jumping box with different height $(20 \mathrm{~cm}, 40 \mathrm{~cm}, 60 \mathrm{~cm}, 80 \mathrm{~cm})$, hurdle of different size $(20 \mathrm{~cm}, 30 \mathrm{~cm}, 40 \mathrm{~cm})$, weight adjustable barbell (30 kg, $35 \mathrm{~kg}, 40 \mathrm{~kg}$ ). 
Study method. Expert interviews. We have interviewed with the experts and coaches about the lower limbs explosive method in the field of physical training in Shanghai.

Experimental method. The plyometric training was used in experimental training, lasting 8 weeks, 3 times every week, the training time for 40 minutes. (Note: the plyometric training is different according to the experimental process arrangement). The control group used the traditional resistance strength training.

Table 1 Training plan

\begin{tabular}{|c|c|c|c|}
\hline \multicolumn{2}{|l|}{ Control group } & \multicolumn{2}{|l|}{ Experimental group } \\
\hline Training action & $\begin{array}{l}\text { Strength and } \\
\text { measurement }\end{array}$ & Training action & $\begin{array}{l}\text { Strength and } \\
\text { measurement }\end{array}$ \\
\hline $\begin{array}{l}\text { Squat anterior } \\
\text { portion }\end{array}$ & 8866 & Jump deep & 8866 \\
\hline Battement fondu & 8644 & leap & 6644 \\
\hline Neck squats & 8664 & $\begin{array}{l}\text { Weight-bearing squat } \\
\text { jump }\end{array}$ & 8866 \\
\hline Sitting down pedal & 6444 & Push to the explosive lie & 6444 \\
\hline
\end{tabular}

Three-dimensional force measurement and control system was used to collect the data about vertical jump, squat jump with $20 \mathrm{~kg}$ and 2RM deep squat before and after the experiment test.

Mathematical statistics. The original data of kinematics was firstly analysed by QUAL first YSIS software. The original data of sport dynamics was firstly analysed by KISTLER software.

\section{Experimental results}

Comparison of explosive power of lower limbs before and after experiment.

Table 2 Comparison of indexes about explosive power of lower limbs between before and after experiment

\begin{tabular}{lllll}
\hline Group & $\begin{array}{l}\text { vertical jumping in } \\
\text { situ(cm) }\end{array}$ & $\begin{array}{l}\text { Stop time in } \\
\text { air(s) }\end{array}$ & $\begin{array}{l}\text { squat jump with } \\
20 \mathrm{~kg}(\mathrm{~W})\end{array}$ & $\begin{array}{l}\text { 2RM deep squat } \\
(\mathrm{kg})\end{array}$ \\
Control & $59.0 \pm 2.7$ & $0.63 \pm 0.009$ & $4305 \pm 29$ & $94 \pm 3.6$ \\
Experiment & $59.3 \pm 3.2$ & $0.63 \pm 0.012$ & $4296 \pm 43$ & $93 \pm 2.7$ \\
T test & $\mathrm{P}>0.05$ & $\mathrm{P}>0.05$ & $\mathrm{P}>0.05$ & $\mathrm{P}>0.05$ \\
\hline
\end{tabular}

It is normal that the athlete's body will have reaction in the experiment. There is no statistical difference about the number of skeletal muscle soreness between experimental and control group (P > 0.05). At the same time two groups all have no sign of fatigue. The physiological and biochemical indexes of athletes were in normal range in the experiment. It also shows that the strength and measurement of plyometric training are accepted by young athletes, with no physical damage.

Change of explosive power of lower limbs for control group before and after experiment. Table 3 Change of explosive power of lower limbs for control group

\begin{tabular}{lcccc}
\hline Group & $\begin{array}{l}\text { vertical jumping } \\
\text { in situ(cm) }\end{array}$ & Stop time in air (s) & $\begin{array}{l}\text { squat jump } \\
\text { with } 20 \mathrm{~kg}(\mathrm{~W})\end{array}$ & $\begin{array}{l}\text { 2RM deep squat } \\
(\mathrm{kg})\end{array}$ \\
\hline Control & $59.0 \pm 2.7$ & $0.63 \pm 0.009$ & $4305 \pm 29$ & $94 \pm 3.6$ \\
Experiment & $60.2 \pm 1.4$ & $0.62 \pm 0.016$ & $4336 \pm 35$ & $99 \pm 2.6$ \\
T test & $\mathrm{P}>0.05$ & $\mathrm{P}>0.05$ & $\mathrm{P}>0.05$ & $\mathrm{P}<0.05$ \\
\hline
\end{tabular}

There were no significant difference on the three indicators of lower limbs explosive power (in situ vertical jump increase $1 \mathrm{~cm}$, weight $20 \mathrm{~kg}$ maximum power output increase $31 \mathrm{w}$, single vertical jump time shortens 0.01 seconds in the air) before and after experiment after traditional training for 8weeks $(\mathrm{P}>0.05)$. The index of 2RM deep squat increases $5 \mathrm{~kg}$, there was a significant change before and after the experiment $(\mathrm{P}<0.05)$. 


\section{Change of explosive power of lower limbs for experimental group before and after experiment.}

Table 4 Change of explosive power of lower limbs for experimental group

\begin{tabular}{lcccc}
\hline Group & $\begin{array}{l}\text { vertical jumping } \\
\text { in situ(cm) }\end{array}$ & $\begin{array}{l}\text { Stop time in air } \\
(\mathrm{s})\end{array}$ & $\begin{array}{l}\text { squat jump with } \\
20 \mathrm{~kg}(\mathrm{~W})\end{array}$ & $\begin{array}{c}\text { 2RM deep squat } \\
(\mathrm{kg})\end{array}$ \\
\hline Control & $59.3 \pm 3.2$ & $0.63 \pm 0.012$ & $4296 \pm 43$ & $93 \pm 2.7$ \\
Experiment & $65.7 \pm 1.6$ & $0.64 \pm 0.016$ & $4667 \pm 49$ & $94 \pm 1.6$ \\
T test & $\mathrm{P}<0.05$ & $\mathrm{P}>0.05$ & $\mathrm{P}<0.05$ & $\mathrm{P}>0.05$ \\
\hline
\end{tabular}

Table 7 shows that there were significant difference on the two indicators of lower limbs explosive power (in situ vertical jump increase $6.4 \mathrm{~cm}$, weight $20 \mathrm{~kg}$ maximum power output increase $371 \mathrm{w}$ ) before and after experiment after traditional training for 8weeks $(\mathrm{P}<0.05)$. The single vertical jump time increases 0.01 seconds in the air, $2 \mathrm{RM}$ deep squat increases $5 \mathrm{~kg}$, there was a significant change before and after the experiment $(\mathrm{P}>0.05)$.

Comparison of explosive power of lower limbs for athletes of two groups before and after experiment.

Table 5 Comparison of indexes about explosive power of lower limbs for two groups before and after experiment

\begin{tabular}{lcccc}
\hline Group & $\begin{array}{l}\text { vertical jumping } \\
\text { in situ(cm) }\end{array}$ & $\begin{array}{l}\text { Stop time in air } \\
(\mathrm{s})\end{array}$ & $\begin{array}{l}\text { squat jump with } \\
\text { 20kg(W) }\end{array}$ & $\begin{array}{l}\text { 2RM deep squat } \\
(\mathrm{kg})\end{array}$ \\
\hline Control & $60.2 \pm 1.4$ & $0.62 \pm 0.016$ & $4336 \pm 35$ & $99 \pm 2.6$ \\
Experiment & $65.7 \pm 1.6$ & $0.64 \pm 0.016$ & $4667 \pm 49$ & $94 \pm 1.6$ \\
T test & $\mathrm{P}<0.05$ & $\mathrm{P}>0.05$ & $\mathrm{P}<0.05$ & $\mathrm{P}<0.05$ \\
\hline
\end{tabular}

Table 8 shows that there were significant difference on the two indicators of lower limbs explosive power (the average of situ vertical jump of experimental group increase $5.5 \mathrm{~cm}$ compared with control group, the average of weight $20 \mathrm{~kg}$ maximum power output of experimental group increase $331 \mathrm{w}$ compared with control group) before and after experiment after traditional training for 8weeks $(\mathrm{P}<0.05)$. There was no significant difference in the single vertical jump time between control and experimental group $(\mathrm{P}>0.05)$. The average of $2 \mathrm{RM}$ deep squat for control group is higher $5 \mathrm{~kg}$ than that of experimental group, with significant difference $(\mathrm{P}<0.05)$.

\section{Experimental analysis}

Plyometric training can improve explosive power of lower limbs for young athletes. 20 young athletes (10 for the experimental group and 10 the control group) were selected to do plyometric and traditional resistance strength trainings. The average of in-situ vertical jump in experimental group increases $5.5 \mathrm{~cm}$ compared with control group. The average of squat jump maximum power output with $20 \mathrm{~kg}$ in experimental group is higher (331W) than that of control group. There are significant differences for two indicators between experimental and control groups $(\mathrm{P}<0.05)$.

Experimental results show that the fast strength in the experimental group significantly improves after 8 weeks plyometric training, higher than control group. Rapid changes in power quality can make athletes play a high quality at high speeding get a critical strike in the game. For volleyball, good fast power quality guarantee the jumping height of athlete, height of blocking, continuous technical capabilities and the ability of quick spiking. It is same for badminton sport. Good explosive power of lower limbs can guarantee the fast moving ability of the athletes in the game and also increase the height of the athletes to kill the ball and strength.

The relationship between lower limbs explosive power and maximum strength for youth athletes. The results show that there are two main ways in the explosive growth. Firstly, the increase is based on the maximum muscle strength. Secondly, the increase is based on the nerve - muscle coordination ability. The maximum muscle strength of athletes does not obviously increase, but the explosive power of lower limbs significantly increases in the plyometric training of young athletes for 
8 weeks. It also suggests that the significant increase of explosive power of lower limbs benefits from the athletes nerve, increase quick of muscle coordination ability.

The conclusion that the maximum muscle strength of athletes does not obviously increase is similar with the results from literature. Because we consider the physical and mental characteristics of adolescent athletes in the process of the experiment, the strength of plyometric training for young athletes is lower than that of adult athletes. We should consider the buffer time to the ground of athletes, shorting the time of muscle from centrifugal shrinkage to radial shrinkage in the experiments. In the condition of reducing the potential joint venture for young in plyometric training, we also can receive significantly increase of explosive force.

\section{Conclusions and recommendations}

Conclusions. Plyometric training has a significant effect on improvement of explosive power of lower limbs for young athletes.

Plyometric training has no significant effect on improvement of biggest strength of lower limbs for young athletes. For the training of biggest strength, normal training is better than plyometric training.

For the maximum of muscle strength, the traditional resistance is better than plyometric training.

Recommendations. The plyometric training must do step by step for young athletes. We should consider the physical characteristics of young athletes, control the reasonable training strength and strengthen medical supervise and test physiological and biochemical indexes in the process of training.

The selected action of plyometric training for young athletes should meet the special needs of exercise. The power angle in the plyometric training is same with the power angle of special action. It can ensure maximum improve special fast strength ability for young athletes.

We cannot always consider the height of deep jump, The key of training is the control of buffer time and speed of jump for athletes. The muscle of centripetal and centrifugal contraction should be treated as a whole. We should pay more attention to rapid transformation of centrifugal shrinkage, especially in the training of young athletes.

\section{References}

[1] Bu Y F, Li S M, Han J, et al. The Nonlinear analysis between drop-jump of different depth and distance combination and the effect of jump[J]. Journal of TUS, 2006, (6): 484-487.

[2] Han J, Li S M, Bu Y F, et al. Compare research on take2off effect of drop2jump and app roach jump[J]. Journal of Ludong University, 2007, 23(3): 285-288.

[3] Sun Z J, Zhang J P, Wang L, et al. Effect of the jumping-depth and jumping-up exercisein the training of the super -equilength strength on the physical ability of the hurdle -race atheletes[J]. Journal of Shangdong Physical Education Institute, 1999, 15(3): 63-65.

[4] Meng Z L, Zhang Q L. Experimental study on the effect of flexors and extensors muscular torque and angles of knee joint on the CMJ height[J]. Zhejiang Sport Science, 2004, 26(3): 100-103.

[5] Huang Z G, Wang Y. Experiment study of squat jump during different knee angles in biomechanics[J]. Journal of Xian Institute of Physical Education, 2000, 17(1): 89-91.

[6] Jing L X, Liu Y, Tian S L. Analysis on lower extremity joint functions during plyometric exercise with different loads[J]. Sports Science, 2009, 29(5): 50-53. 